\title{
Challenges and prospects of practical-oriented training in the sectors of tourism and hospitality
}

\author{
Tatiana Zainullina ${ }^{1, *}$ and Irina Kedrova $^{1}$ \\ ${ }^{1}$ Don State Technical University, Gagarina Sq., 1, Rostov-on-Don, 344000, Russia
}

\begin{abstract}
The article studies the development of practical-oriented education as an integral part of the educational process for students in the field of tourism and hospitality. The main challenges faced by experiencebased education are highlighted and solutions are proposed. In particular, the difficulties associated with the organization of various types of practices, the lack of a rating of universities in the field of tourism and hospitality in Russia are considered. The ranking of foreign educational institutions was an example. Practical developments are also presented, which made it possible to combine the efforts of educational organizations and employers in the development of practical-oriented education.
\end{abstract}

\section{Introduction}

The concept of "practical-oriented vocational education" and "problem-oriented training" can be found in the scientific works devoted to the problems of education and in regulatory documents. At the same time, the fact of different interpretations of the concept and its essence leads to the fact that there is a different understanding of this phenomenon among specialists in the education sector. This reveals itself in the highest form when it comes to the personal levels of education (professional, secondary special, higher, etc.), as well as different areas of training, since the requirements for specialists can vary from one area to another. That is why paying attention to the training of personnel in the field of service, tourism and hospitality are extremely necessary nowadays, since the volume of practical skills of these specialists is very wide and includes not only relevant knowledge, but also personal qualities such as sociability, stress tolerance, literate speech etc. Practicaloriented education is education, the main purpose of which is to form practical work among students, which is demanded by employers today, as well as to create an understanding of how the competencies obtained during training can be applied in practice.

\section{Review of scientific sources}

The meaning and concept of problem-oriented and practice-oriented education is considered and studied by such authors as Duch, B. J., Groh, S. E, Allen, D. E. (2001) [1], Grasha, A. F. (1996) [2], John R. Savery (2006) [3], Labaree, D. F. 2003 [4], Chang, J., Chalcraft, D. and Rieple, A. (2015) [5]. In his research, Professor Woods, D. R. (1996,

\footnotetext{
* Corresponding author: tat-zajnullina@yandex.ru
} 
2005) [6.7] notes that graduates are more positive about their acquired "techno-logical skills" than about their knowledge of the subject. Unlike "theory-based learning," practicebased learning" requires a student to study and apply theory in a real working environment from the very beginning. Problematic and practical approaches to learning have a long history of supporting learning based on experience. Psychological research and theory show that by giving students the opportunity to learn from their own experience in solving problems, they can study both content and thinking strategies. Problem-oriented learning (PBL) is a learning method in which students learn to facilitate problem solving. In PBL, student education focuses on a complex problem that does not have the only right answer. The theory of problem-oriented and practice-oriented education and training was developed by the authors: Barrows, H. S. (1986) [8], Savery, J. R., \& Duffy, T. M. (1995) [9], Albanese, M. A., and Mitchell, S. (1993) [10]. The model of practical and problem-oriented education and the main stages of its formation are considered in the works of Glazer, E. (2010) [11]. On September 13, 2017, Professor Stephen Billett made a presentation at the UNESCO Mass in Paris on current research on learning through work, integrating work experience into educational programs, and the status of vocational education. Features of learning through practice are disclosed in books edited by Billett S. (2020) "Learning Through Practice: Models, Traditions, Orientations and Approaches" [12]. Pirogova O.V. (2017) [13] considers the features of practical-oriented education in a tourist university. Polisadov S.S. (2017) shares four approaches to practical-oriented education and notes that practical-oriented education is based on the unification of fundamental general education and applied vocational training [14]. Spatar-Kozachenko T.I., Morozan O.V., Petrienko N.S. (2018) denote the problems of professional training of personnel in the field of tourism and hospitality [15]. Kavkaeva N.V., Medyantseva S.G. (2015) consider a multi-level model of practical-oriented training of service and tourism specialists [16].

\section{Methods of Research}

The following research methods were used in the work: analysis of scientific sources, synthesis of scientific ideas, foreign experience, description of the concept of practicaloriented education and training, questionnaire of managers of employer enterprises.

By preparation of this research by authors the questionnaire was developed for employers with the purpose to find out as far as they are happy with quality of training of graduates of the direction of preparation 43.03.02 "Tourism" and 43.03.03 "Hotel business" of faculty "Service and tourism" of the Don state technical university and that stops employers at employment of young specialists. The survey was attended by the heads of 35 hotel and tourist enterprises of the Rostov region. From the whole survey, I would like to highlight several answers presented in Figures 1 and 2. An analysis of the influence of the participation in the World Skills Russia championships of students of the Hotel Business training direction on the introduction of practical-oriented education in the educational process and interaction with hotel enterprises in Rostov-on-Don was also carried out.

\section{Results and Discussion}

If we consider the foreign experience of organizing education in the field of tourism and hospitality, we should start with a review of educational institutions in this area. Consider the top 10 global institutes involved in training in the field of hospitality and tourism, compiled on the basis of the results obtained by the marketing firm TNS (Taylor Nelson Sofres) в 2013 г. и Global Hospitality Portal в 2016 г. Taylor Nelson Sofres (TNS) is one of the leading marketing research and information groups, as well as the world's largest 
provider of research and analysis based on them, the authors present the following results (Table 1).

Table 1. Rating of higher education institutions in the field of tourism and hospitality.

\begin{tabular}{|c|c|c|c|c|c|}
\hline $\begin{array}{l}\text { Rating } \\
\text { TNS }\end{array}$ & $\begin{array}{l}\text { Place } \\
\text { GHP }\end{array}$ & $\begin{array}{l}\text { Educational } \\
\text { Organization }\end{array}$ & Location & $\begin{array}{c}\text { Undergraduate } \\
\text { program } \\
\text { (duration of } \\
\text { study) }\end{array}$ & $\begin{array}{l}\text { Tuition } \\
\text { Fees }\end{array}$ \\
\hline 1 & 1 & $\begin{array}{c}\text { Ecole Hoteliere } \\
\text { de Lausanne }\end{array}$ & $\begin{array}{l}\text { Lausanne, } \\
\text { Switzerland }\end{array}$ & $\begin{array}{c}3,5 \text { year } \\
(7 \text { semesters }+2 \\
\text { internships each } 6 \\
\text { month })\end{array}$ & $\begin{array}{l}35.600- \\
38.800 \mathrm{CHF} \\
\text { per year }\end{array}$ \\
\hline 2 & 3 & $\begin{array}{c}\text { Glion Institute } \\
\text { of Higher } \\
\text { Education }\end{array}$ & $\begin{array}{l}\text { Glion, Bull, } \\
\text { Switzerland }\end{array}$ & $\begin{array}{c}3,5 \text { year } \\
\text { (2 internships } \\
\text { each } 6 \text { month) }\end{array}$ & $\begin{array}{l}29000 \mathrm{CHF} \\
\text { per semester }\end{array}$ \\
\hline 3 & 4 & $\begin{array}{l}\text { Les Roches, } \\
\text { International } \\
\text { School of } \\
\text { Hotel } \\
\text { Management }\end{array}$ & $\begin{array}{l}\text { Crane-Montana, } \\
\text { Switzerland }\end{array}$ & $\begin{array}{c}3 \text { years } \\
\text { (6 semesters) }\end{array}$ & $\begin{array}{c}33850- \\
36050 \mathrm{CHF} \\
\text { per year }\end{array}$ \\
\hline 4 & 2 & $\begin{array}{c}\text { Cornell } \\
\text { University }\end{array}$ & Ithaca, USA & 4 years & $55000 \$$ all \\
\hline 5 & 6 & $\begin{array}{l}\text { Hotel School } \\
\text { The Hague }\end{array}$ & $\begin{array}{l}\text { The Hague, } \\
\text { Netherlands }\end{array}$ & 4 years & $\begin{array}{c}\text { from } 10330 \\
€ \text { per year }\end{array}$ \\
\hline 6 & - & $\begin{array}{l}\text { Les Roches } \\
\text { International } \\
\text { School of } \\
\text { Hotel } \\
\text { Management }\end{array}$ & Marbella, Spain & $\begin{array}{c}3,5 \text { year }(2 \\
\text { internships each } 6 \\
\text { month) }\end{array}$ & $\begin{array}{c}\text { from } 16165 \\
€ \text { per } \\
\text { semester }\end{array}$ \\
\hline 7 & 9 & $\begin{array}{l}\text { Oxford } \\
\text { Brookes } \\
\text { University } \\
\end{array}$ & Oxford, UK & 4 years & $\begin{array}{l}\text { from } 13410 \\
£ \text { per year }\end{array}$ \\
\hline 8 & - & $\begin{array}{c}\text { Blue } \\
\text { Mountains } \\
\text { International } \\
\text { Hotel } \\
\text { Management } \\
\text { School }\end{array}$ & $\begin{array}{l}\text { Lyura, Sydney, } \\
\text { Australia }\end{array}$ & 2,5 year & $\begin{array}{c}22920 \\
\text { \$AUD per } \\
\text { semester }\end{array}$ \\
\hline 9 & 8 & $\begin{array}{c}\text { Hotel School } \\
\text { Vatel }\end{array}$ & $\begin{array}{l}\text { Paris, Lyon, Nimes, } \\
\text { Bordeaux, France }\end{array}$ & 3 years & $\begin{array}{c}\text { from } 12500 \\
€ \text { per year }\end{array}$ \\
\hline 10 & 10 & $\begin{array}{l}\text { Cesar Ritz } \\
\text { Colleges }\end{array}$ & $\begin{array}{l}\text { Le Bouvre, Brig, } \\
\text { Switzerland }\end{array}$ & $\begin{array}{l}3 \text { years }(10 \\
\text { semesters })\end{array}$ & $\begin{array}{c}19.600- \\
21.500 \mathrm{CHF} \\
\text { per year }\end{array}$ \\
\hline
\end{tabular}

It is not possible to monitor the rating of all universities in the field of tourism and hospitality in Russia, there are data only in general for universities of the Russian Federation, and in this area, and there are statistics in educational institutions in Moscow. Therefore, it was not possible to conduct a comprehensive comparative analysis of the quality of graduate training in the sector of tourism and hospitality. In Russia, there was a harmful perception that professional skills could be obtained only in the process of work, that is, after graduation, and not in its process. Many managers did not pay attention to the applicant's special education when hiring them, assuming that the level of practical training at universities was extremely low. Since tourism and hospitality was an area where practical training during training was more important than fundamental theoretical knowledge, the problem of meeting the qualifications of graduates of educational 
institutions preparing personnel for the tourism industry was quite acute for employers in modern Russian conditions. The question arises, which is not enough for Russian education in the field of tourism and hospitality, because often, our graduates cannot continue their professional education abroad precisely because of the lack of practical skills. It was obvious that all practices (training, production, pre-diploma) were the basis of practical experience, and were aimed at acquiring that experience by type of professional activity. Each employer wishes to hire a trained specialist with work experience. Here, practitioners are accumulators of experience. At the same time, it is worth noting that most Western schools of tourism and hotel business are based on children's hotels, and the highest category, respectively, all work skills students comprehend in conditions as close to reality as possible. As can be seen from table 1, most courses already include internships, which hotels partially pay students. The problem of practical training in Russian Universities lies in the fact that there is no clear order from employers of a particular industry. Moreover, most of the students do not know whether they will work in the specialty (and often are not going to), this decision is formed already in the process of studying at the university, since most applicants choosing a future profession are poorly represented by who they will leave the walls of the university in 4 years. The reason for this is also the system of organizing practice and in general the interaction of educational organizations preparing specialists for the hotel business and tourism with potential employers. As a rule, employers do not want to conclude target contracts, since they do not know how many specialists they will need and at what time period. Conducting practice for students is a kind of "burden" for the employer, because it is necessary to distract specialists from their new work for classes with trainees. Some results from developed the questionnaire for employers with the purpose to find out as far as they are happy with quality of training of graduates of the direction of preparation 43.03.02 "Tourism" and 43.03.03 "Hotel business" of faculty "Service and tourism" of the Don state technical university are presented in the pictures.

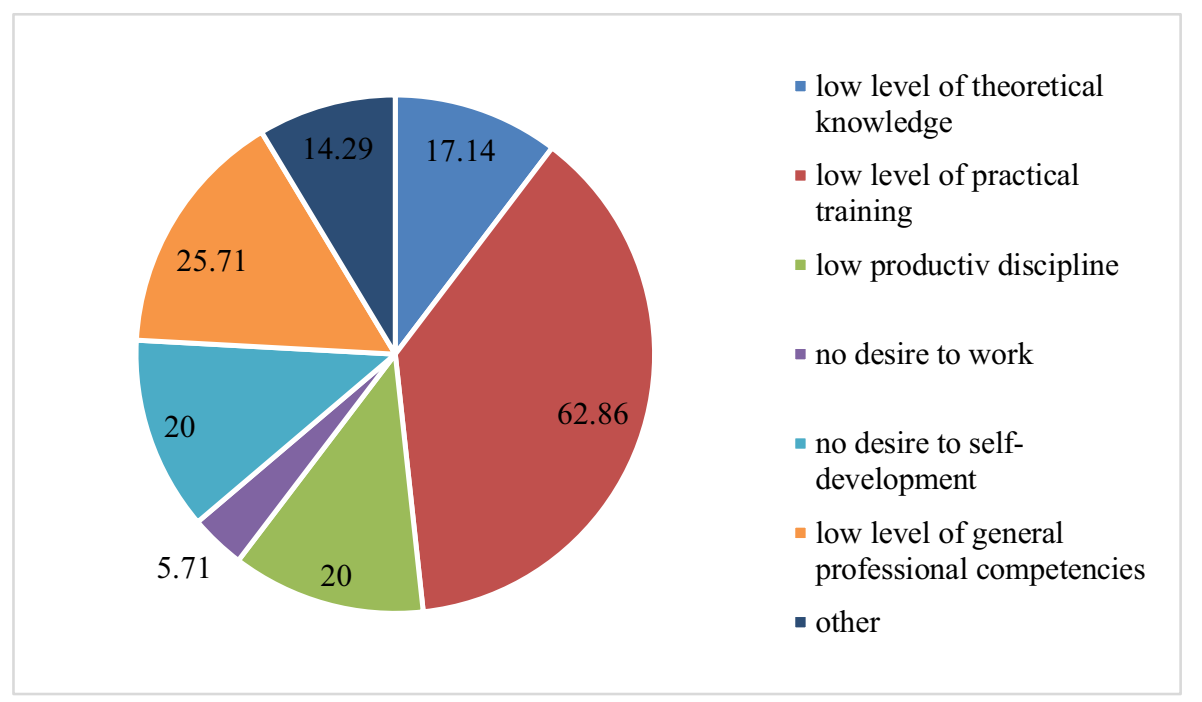

Fig. 1. What shortcomings in the preparation of students you could indicate $(\%$ of the total number of respondents). 


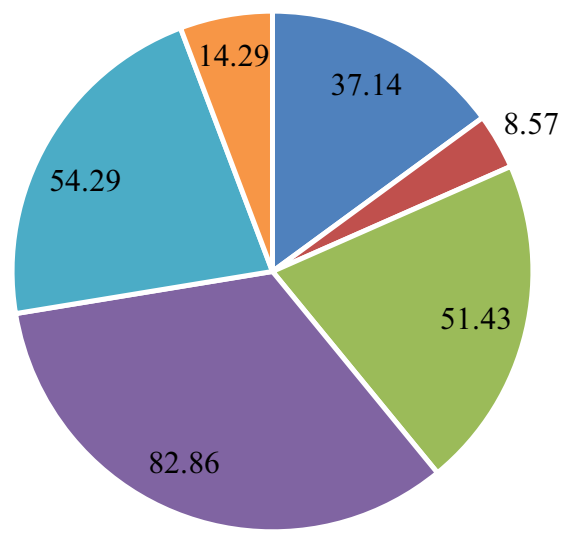

- high level of theoretical knowledge

- high level of practical training

- readiness for self-study and career development

- desire to work

- knowledge of communication skills

" other

Fig. 2. What advantages do students of the faculty "Service and Tourism" DSTU have (\% of the total number of respondents).

The survey also showed that the first place among the factors that cause concerns when hiring graduates is the lack of experience (practice), so 16 out of 35 respondents answered. In second place was allocated the factor "long training time (waste of time), the need for training by the main employees" - 8 out of 35 respondents. In third place, employers put the reason - "inflated wage requirements for graduates with experience" - 6 respondents, and only 3 respondents replied that "nothing stops, the lack of experience is not the worst, the main desire to work and study," although there were other answers. The solution to the problem of practical-oriented training is to combine deep theoretical training and the development of practical skills throughout the training in constant contact with employersrepresentatives of tourist and hotel enterprises. Only in this case is it possible to ensure the necessary quality of training of personnel resources for the tourist and hotel sector. In addition, in the development of an undergraduate or master's degree education program, as well as the content of disciplines and modules, it was necessary to focus on the curricula of flagship educational institutions in this area, but as mentioned above, there was no rating of such universities in Russia, which caused significant difficulties in setting target guidelines. The filling of disciplines should be based on practical and situational material directly related to the activities and field of professional interests of the future graduate. To solve this problem, it is proposed not just to conclude targeted agreements on the practice of students, but also to train specialists under the specific employer throughout the entire training period, with the assignment of the place of practice to the student and its distribution to a specific tourist or hotel enterprise after graduation. The hotels are also interested in the practices that have taken place in the hotel, while still working on a permanent basis in the course of study at the university. Some employers may offer free training for hotel staff (travel agencies), payment of second foreign language courses for students, and possibly payment of scholarships to students based on a further employment contract. A promising direction of practical-oriented training is the already changing system of combining practice and visiting internships in hotels and travel companies in the high season. The creation of the so-called "sample-enterprise" (for example, travel agencies) based on the university will also allow simulating real working conditions. As part of this experiment, students can try their hand as a tour agent, tour developer, and tour organizer. Imitation of the psychological environment close to the project, the relationship in the team 
and the functional distribution of duties in the implementation of the real technological processes taking place at the tourist enterprise will allow the trainees to understand and feel the features of the future profession. Certainly, in the current non-stable situation, some activities might seem impossible, but awareness of the problem was already a step towards solving it. Another serious problem that prevents the development of practical-oriented education in the field of tourism and hospitality is the low level of proficiency in foreign languages among students. We completely understand that any employee of the 4-5 star hotel, especially administrators, who are the main link in interacting with the client, is required to speak a foreign language, namely English. Unfortunately, today many tourist and hotel enterprises neglect this requirement. An attempt to reverse this situation was the inclusion in the list of com-petitions "World Skills Russia" ("World Skills Russia") of the competence of "Hotel Administration" (E57 WSE "Hotel Reception") and "Tourism" (R9 "Tourism"). The Union "Agency for the Development of Professional Communities and Workers" Young Professionals (World Skills Russia) "was created in Russia in 2014 with the aim of promoting the development of professional education in Russia in accordance with the standards of the international organization "World Skills International". All these measures provide the Russian economy with highly qualified personnel, increase the role of professional training, including by holding professional skills championships. For the purpose of increase in professional level of the championships of various levels studying within carrying out the Specification of the standard of competence (World Skills Standards Specifications WSSS) - the list of skills which the expert in the corresponding competence, with the indication of percentage of their use and importance within preparation of evaluation criteria has to possess was developed. As an example, the WSSS "Hotel Administration" highlighted the knowledge, skills and skills that the hotel administrator should have. This knowledge, skills and skills are based on daily practical work, that is, you can get this knowledge in theory, but you can consolidate and bring to perfection - only in practice. At the same time, I would like to note that most of the competitive tasks (from 50 to $70 \%$ of the tasks) of the World Skills Russia championships in this competence must be performed in English, that is, knowledge of a foreign language is mandatory. As a result of the fate of DSTU in 2018-2019 in the movement "World Skills Russia," an understanding is created of the need to develop the interaction of the educational process with employer enterprises. This statement was confirmed by the effectiveness of participation of students in the World Skills Russia championships at various levels, from in-university to interuniversity, including qualifying stages. The basis of competitive tasks is the situations (including extraordinary ones) that take place in the hotel daily, this is why only practice at hospitality industry enterprises allowed participants and experts to pass all qualifying tests and reach the final of the III national inter-university championship "Young Professionals" ("World Skills Russia" ) the largest hotel enterprises in Rostov-on-Don participated in preparation for the competition: These hotel enterprises are non-financial employers and, as a result of such interaction, provided places of practice and even jobs for students in the "Hotel Business" direction of the DSTU.

\section{Conclusion}

To conclude all that is mentioned above, there are the following statements:

1. Practical-oriented education is the necessary basis for training personnel in the field of tourism and hospitality, since personnel training in this field directly affects the quality of service. The practical orientation throughout the entire period of theoretical training, combined with internships in tourist and hotel enterprises, will allow training specialists to meet the requirements of employers. 
2. An analysis of the survey data of heads of tourism and hospitality enterprises revealed weak links in the preparation of publications according to employers - the main of which is the low level of practical training and the need for retraining in the process of work.

3. The more universities will be in the participation and holding of the World Skills Russia standard championships, the more practical and oriented education in the field of tourism and hospitality will become. All the criteria for assessing participants are exclusively practical, for example: to effectively cope with regular and extraordinary events, to know and understand cultural, historical and tourist information relating to a given city or region, to know the peculiarities of intercultural communication with guests, the features and procedures for dividing different categories of rooms in accordance with the floor plan of the hotel, to make various types of reservations and use different ways of booking numbers, to be able to carry out the procedure for identifying the identity of the guest, etc.

\section{References}

1. B.J. Duch, S.E. Groh, D.E. Allen, The power of problem-based learning (University Delaware, Sterling, VA, 2001)

2. A.F. Grasha, Teaching with style: A practical guide to enhancing learning by understanding teaching and learning styles (Alliance Publishers, Pittsburgh, 1996)

3. R. John, Savery Overview of Problem-Based Learning: Definitions and Distinctions Article (2006)

4. D.F. Labaree, Educational Researcher 32(4), 13-22 (2003)

5. J. Chang, D. Chalcraft, A. Rieple, Research in Management Learning and Education (RMLE) (Eastern Academy of Management, Lima, Peru, 2015)

6. D.R. Woods, Problem-based learning: Helping your students gain the most from PBL (1996).

7. D.R. Woods, Problem-based learning (McMaster University, Hamilton, 2005)

8. H.S. Barrows, Based Learning Methods. Medical education 20(6), 481-486 (1986)

9. J.R., Savery, T.M. Duffy, Educational technology 35(5), 31-38 (1995)

10. M.A. Albanese, S. Mitchell, Acad. Med. 68, 52-81 (1993)

11. E. Glazer, Emerging Perspectives on Learning, Teaching, and Technology, Global Text (2010)

Emerging_Perspectives_Learning.pdf

12. S. Billett, Learning Through Practice Models, Traditions, Orientations and Approaches (Griffith University, Australia, 2020)

13. O.V. Pirogova, Interactive Science 4(14), 68-71 (2017)

14. S.S. Polisadov, News of Tom Polytechnic University 2, 23-29 (2017)

15. T.I. Spatar-Kozachenko, O.V. Morozan, N.S. Petrienko, Plus Service 12(3), 44-51 (2018)

16. N.V. Kavkaeva, S.G. Medyantseva, Vestnik KemGU 2-7(62), 86-91 (2015) 